\title{
Base erosion and profit shifting by Google and platform market competition in Korea
}

\author{
Taehee Lee $^{1^{*}}$ \\ ${ }^{1}$ Kookmin University, College of Business Administration, 77 Jeongnueung-ro, Seoul, Korea
}

\begin{abstract}
The adoption of Google Taxes is often mentioned with respect to corporate taxes avoided for a MNE that does not have a permanent establishment in the domestic market. None has looked at the implications of avoided corporate taxes on platform market competition. Using Google as a representative MNE that employs the DIDS framework, the present study, using publicly disclosed financial statements information, documents that if a MNE with a permanent establishment in Korean market had generated profits of $520.9 \mathrm{~b}$ KRW in 2017.
\end{abstract}

Key words: profit, market, google, erosion

\section{Introduction}

Multinational enterprises (MNE's) often exercise transfer pricing strategies among her subsidiaries to shift profits across different jurisdictions for various purposes. Such practices have long been subject to regulatory scrutiny, mainly by national taxing agencies, for profit shifting by MNE's inevitably entails avoided corporate income taxes on the part of the national tax agencies. OECD first coined the acronym BEPS (Base Erosion and Profit Shifting) to reflect the phenomenon and accordingly launched BEPS Action Plan in $2014[1]$.

At the age of digital economy, the issue of BEPS has developed into a more heated controversy as MNE's, notably Google, Apple, Facebook, Amazon (GAFA), heavily engage in R\&D activities, create intellectual properties (IP's), and use transfer pricing of IP's as a tool for transnational tax planning. MNE's lease (licence to use) IP's to their affiliates in low tax jurisdictions and these affiliates sublease IP's to another affiliates with customer base in high tax jurisdictions.

Such practices of GAFA-like MNE's (hereafter tech MNE's) are more controversial than those of traditional MNE's because tech MNE's do not establish a permanent establishment $(\mathrm{PE})$ in their respective customer base countries. Most of the time, tech MNE's engage in business activities via intangible assets (IP's). An "avoided PE's (APE)" is then defined as a foreign company (usually a MNE) who makes substantial sales through activity in the customer base country while avoiding the creation of a taxable presence in that jurisdiction.

Like many other countries in EU, a heated debate has arisen recently regarding BEPS issue in Korean platform market by tech MNE's. This study adds some evidence to the

\footnotetext{
* Corresponding author: thlee@ $@$ kookmin.ac.kr
} 
debate by estimating Google's sales, operating expenses, income taxes in Korea if Google were subject to Korean tax law. The study also draws some implications as to what impact tech MNE's BEPS activities has on competition in the Korean platform market. Prior to the current study, none has addressed the issue using accounting figures based on publicly disclosed financial information.

[2] review and critique two prominent theories in the international business and international economics literatures regarding the role of multinational enterprises (MNEs) in host country development: the "spillovers" perspective on the impact of MNE investment in host countries and the liabilities of foreignness (LOF) view that specifies the constraints MNEs must overcome to succeed in local, developing country markets.

According to $[3,4]$, MNEs are central agents, they argue, for promoting economic growth meanwhile they complement domestic savings, transfer technology and management skills, increase competition, and stimulate entrepreneurship, but another group of researchers opposes this view suggesting that MNEs are more likely to crowd out local firms, use technology that is inappropriate for local circumstances, actively constrain potential technology spillovers, and reduce the domestic capital stock and tax basis due to transfer price manipulation and excessive profit repatriation $[5,6]$.

\section{Documentation of Profit Shifting in Korean Market}

\subsection{Estimation of sales revenue}

The present paper estimates the sales revenue of Google in Korea by using publicly available information disclosed by Google Asia Pacific Ltd (hereafter, Google Singapore). From the financial statements filed to Accounting and Corporate Regulatory Authority (ACRA), a national regulatory body of Singapore, sales revenue of Google Singapre amounted to $\$ 15.7 \mathrm{~b}$ in 2017 [7]. 


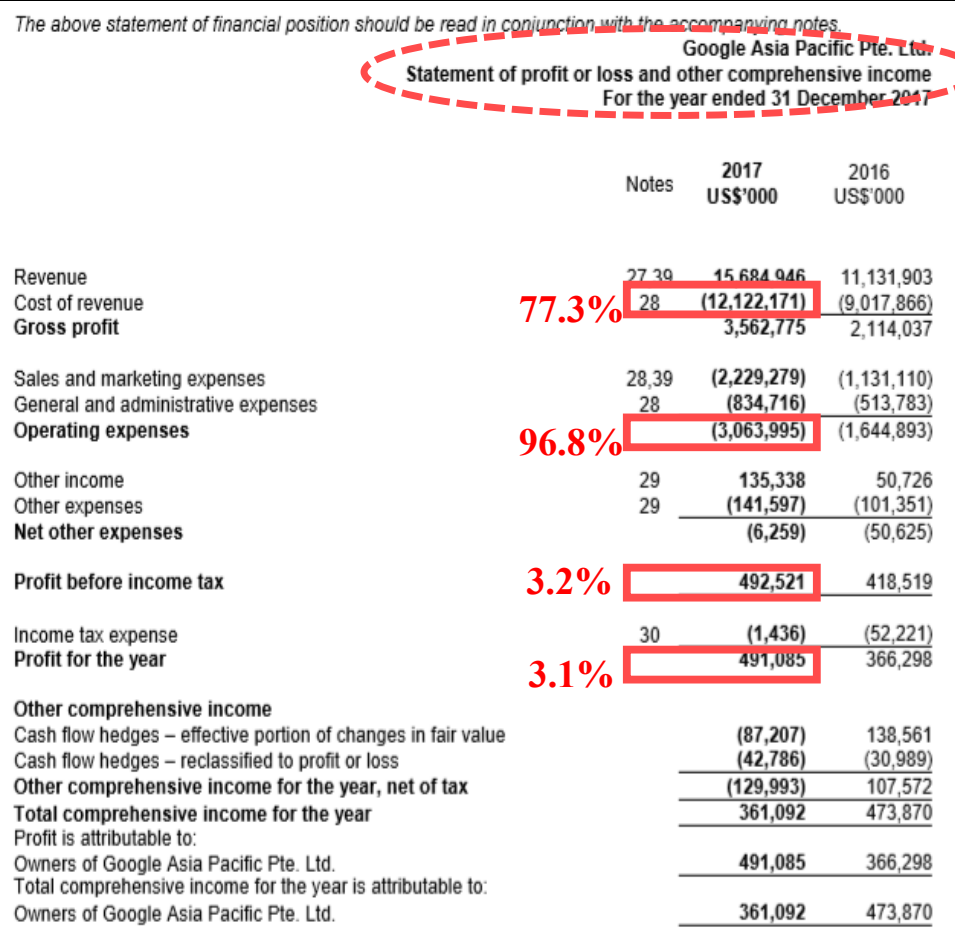

Fig. 1. Revenues, costs and profits of Google Singapore in ratios

Source: Own processing.

Given that sales revenue of $\$ 15.7 \mathrm{~b}$ by Google Asia Pacific Ltd. represents the major chunk of Google sales revenue in APAC markets, the portion of Korean market within the APAC markets is estimated based on two underpinnings.

First, footnote 10 of financial statements of Google Singapre discloses that the firm hedges foreign currency risk by engaging in foreign currency options and forward contracts of three currencies: Australian Dollar (AUD), Korean Won (KRW) and Japanese Yen (JPY). This implies that the Korean market is likely to be at least in the third with respect to Google sales in APAC markets.

Second, footnote 34 of the same document discloses that the firm has transactional currency exposures arising from sales and purchases that are denominated in currencies other that the functional currency (US\$) of the firm: Japanese Yen (JPY), Singapore Dollar (SGD), Taiwanese Dollar (TWD), Australian Dollar (AUD), Hong Kong Dollar (HKD), Euro (EUR), Malaysian Ringgit (MYR), Korean Won (KRW), New Zealand Dollar (NZD) and Thai Baht (THB). The firm also discloses its exposure to foreign currency risk at the end of the fiscal year as follows.

Taken together, the disclosed financial statements information reveals that the volume of Google transactions in Korea accounts for a significant portion of Google Singapore's foreign exchange risk. Thus, by using the KRW share in the foreign currency risk exposure of Google Asia Pacific Ltd. as a proxy for the proportion of sales revenue in Korea relative to the total sales revenue of Google Singapore. Using the portion of KRW with respect to other currencies with respect to both the receivables and payables, $13.6 \%$ is used as a proxy for the portion of Google sales in Korea.

Multiplying $13.6 \%$ to sales revenue of Google Asia Pacific Ltd. of $\$ 15.7 \mathrm{~b}$ gives an estimated sales revenue of $\$ 2.1 \mathrm{~b}$ in 2017 from the Korean market. 


\subsection{Estimation of costs and profits}

Several points are noteworthy from Google Singapore's comprehensive income statement captured in figure 1. First, cost of revenue and operating expenses are $77.3 \%$ and $96.8 \%$ of sales revenue, respectively. High cost ratios show that Google Singapore is at disadvantage with respect to the cost structure. Further inquiry of financial statements reveals that such cost structure is attributable to high service and license costs. Footnote 28 (Expenses) reveals that service and license costs comprise a large percentage $(87.7 \%)$ of major operating costs.

Second, profitability ratios are extremely low thanks to high cost ratios. Profit before income tax ratio and net income ratio are only $3.2 \%$ and $3.1 \%$ of sales revenue, respectively. This is in sharp contrast to the profitability of its Korean competitor in the Korean platform market, NAVER, which displayed $25.6 \%$ and $16.5 \%$ for the commensurate ratios in 2017.

We next tried to estimate the profits that were shifted from the Korean market. Using the estimated revenue of $\$ 2.1 \mathrm{~b}$ in Section 2.1 of this paper as a starting point, Google profit in 2017 from the Korean market is estimated as follows.

First, the cost of sales (41.1\%) and R\&D expenses (15.0\%), in percentages of sales, of Alphabet Inc., were applied to the estimated sales revenue from the Korean market $(\nVdash 2,139.5 B)$. Had a hypothetical Google subsidiary in Korea with permanent establishment existed, it would have incurred cost of sales and R\&D expenses similar to its ultimate parent company, Alphabet Inc. [8].

Second, sales \& marketing expenses (14.2\%) and general \& administrative expenses $(5.3 \%)$, in percentages of sales, of Google Singapore., were applied to the estimated sales revenue from the Korean market. This assumes that these costs of the hypothetical Google subsidiary in Korea with permanent establishment would resemble those of Google Singapore because they do not include royalty payments of subleasing IP's.

Third, after accounting for major operating expenses (75.7\%), the hypothetical Google subsidiary in Korea with permanent establishment would generate $\$ 520.9 b$ of operating profit in 2017 which is $24.3 \%$ of sales revenue. Given that the hypothetical Google subsidiary is not subject to tax jurisdiction in Korea, such profits are shifted from Korea, thus avoiding corporate taxes which would have been levied in Korea. 
Table 1. Estimating Google sales and profits in Korea

\begin{tabular}{|c|c|c|c|c|}
\hline & \multicolumn{2}{|c|}{ Google Asia Pacific Ltd. } & \multicolumn{2}{|c|}{ Google Sales in Korea } \\
\hline & $\begin{array}{l}\text { Amount } \\
\text { (US\$ B) }\end{array}$ & $\%$ & $\begin{array}{l}\text { Amount } \\
\text { (KRW B) }\end{array}$ & $\%$ \\
\hline Revenue & 15.685 & 100.0 & $2,139.5$ & 100.0 \\
\hline Cost of Sales & 12.122 & 77.3 & 879.7 & 41.1 \\
\hline Gross Profit & 3.562 & 22.7 & $1,259.7$ & 58.9 \\
\hline R\&D expense & & & 320.9 & 15.0 \\
\hline Sales expense & 2.229 & 14.2 & 304.1 & 14.2 \\
\hline Admin. expense & 0.835 & 5.3 & 113.9 & 5.3 \\
\hline Operating exp. & 15.186 & 96.8 & $1,618.6$ & 75.7 \\
\hline Operating income & 0.499 & 3.2 & 520.9 & 24.3 \\
\hline
\end{tabular}

Source: Own processing.

\section{Conclusions}

The adoption of Google Taxes is often mentioned with respect to corporate taxes avoided for the MNE does not have a permanent establishment in the domestic market. None has looked at the implications of avoided corporate taxes on platform market competition. This is particularly important in country like Korea in which domestic platform companies are competing with MNE like Google.

If a domestic firm or a MNE with a permanent establishment in Korean market had generated profit of $\$ 520.9 \mathrm{~b}$ in 2017 , it would have booked a tax expense of $\$ 126.1 \mathrm{~b}$, an equivalent of applying a nominal tax rate of $24.2 \%$ to the pre-tax profit. In 2017

Such profit shifting and exemption of tax expense may have a profound impact on platform market competition. Immensity of the impact on platform market competition can be described in several ways. First, the amount, $\$ 126.1 \mathrm{~b}$ is equivalent of hiring 1,292 toptier SW engineers in Korea. In 2017, an average top-tier SW engineer earned about $0.1 \mathrm{~b}$ a 
year [9]. Alternatively, with the same amount of tax expense, if exempted, a company can hire 1,125 highly skilled SW engineers in U.S. [10]. These equivalence stories imply that profit shifting and tax avoidance by MNE's unleashed by the DIDS structure may have a profound impact on domestic platform markets at the detriment of local platform companies.

\section{References}

1. OECD, "2015 BEPS Action Plan 1: Report on addressing the tax challenges of the digital economy" (2015)

2. J. Oetzel, J.P. Doh, MNEs and development: a review and reconceptualization. Journal of World Business, 44(2), 108-120 (2009)

3. R.E. Caves, Multinational Firms, Competition, and Productivity in Host-Country Markets. Economica, 41(162), 176-193 (1974)

4. N. Lowe, M. Kenney, Foreign investment and the global geography of production: Why the Mexican consumer electronics industry failed. World Development, 27(8), 1427-1443 (1999)

5. M. Haddad, A. Harrison, Are there positive spillovers from direct foreign investment? Evidence from panel data for Morocco. Journal of Development Economics, 42(1), 51-74 (1993)

6. B.J. Aitken, A.E. Harrison, Do domestic firms benefit from direct foreign investment? Evidence from Venezuela. American Economic. Revue, 89(3), 605-618 (1999)

7. Google Asia Pacific PTE. LTD., Financial statements year ended 31 December 2017 (2017)

8. Alphabet Inc., Financial statements year ended 31 December 2017 (2017)

9. Korea Software Industry Association, "Average Wage of S/W engineers in 2017" [online], Available

at : https://search.naver.com/search.naver? where $=$ image $\& \mathrm{sm}=\mathrm{tab}$ jum\&query $=\mathrm{SW} \% \mathrm{EA}$ $\% \mathrm{~B} 8 \% \mathrm{~B} 0 \% \mathrm{EC} \% 88 \% \mathrm{~A} 0 \% \mathrm{EC} \% 9 \mathrm{E} \% 90+\% \mathrm{ED} \% 8 \mathrm{~F} \% 89 \% \mathrm{EA} \% \mathrm{~B} 7 \% \mathrm{~A} 0 \% \mathrm{EC} \% 9 \mathrm{E} \% 84$ \%ЕA\%B8\%88+2017\#imgId=blog32837065\%7C7\%7C221087391588_2146533436\& vType=rollout (2017)

10. U.S. News, "How Much Does a Software Developer Make ?" [online], Available at : https://money.usnews.com/careers/best-jobs/software-developer/salary (2017) 